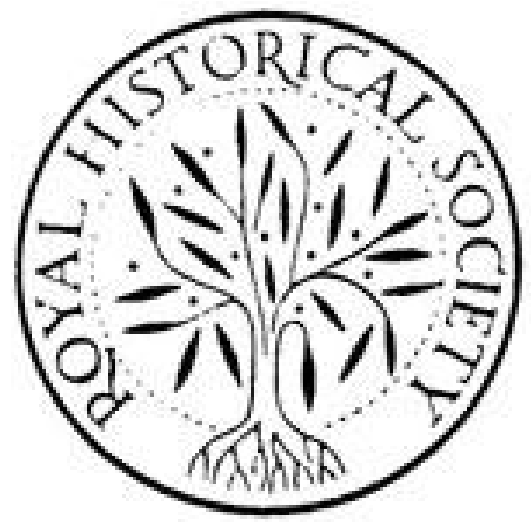

The Relations of the Crown to Trade under James I: (The Alexander Prize Essay for 1898) Author(s): F. Hermia Durham

Source: Transactions of the Royal Historical Society, New Series, Vol. 13 (1899), pp. 199-247 Published by: Cambridge University Press on behalf of the Royal Historical Society Stable URL: http://www.jstor.org/stable/3678131

Accessed: 27-06-2016 06:46 UTC

Your use of the JSTOR archive indicates your acceptance of the Terms \& Conditions of Use, available at

http://about.jstor.org/terms

JSTOR is a not-for-profit service that helps scholars, researchers, and students discover, use, and build upon a wide range of content in a trusted digital archive. We use information technology and tools to increase productivity and facilitate new forms of scholarship. For more information about JSTOR, please contact support@jstor.org.

Cambridge University Press, Royal Historical Society are collaborating with JSTOR to digitize, preserve and extend access to Transactions of the Royal Historical Society 


\title{
THE RELATIONS OF THE CROWN TO TRADE UNDER JAMES I
}

\author{
(The Alexander Prize Essay for 1898)
}

BY F. HERMIA DURHAM

THE reign of James I., covering the first quarter of the seventeenth century, coincides with the period of perhaps the greatest economic confusion in our history. The seeds of England's future greatness as a commercial nation and maritime power had been sown under Elizabeth's rule. In James's reign it was yet too soon for these to bear fruit. It was a critical period for the country which was undergoing an apprenticeship in commerce, trade, and industry. It was as yet doubtful whether she would surmount the difficulties with which she was beset, or whether she would be crushed by their weight.

The reign of Elizabeth had been one of constant foreign danger to the country; James aimed at and indeed succeeded in establishing and maintaining peace with all foreign nations. Yet a contemporary pamphleteer of James's reign complained : 'When was it seen a land soe distressed without wars?'

It is only by reference to the wide and far-reaching changes which were altering the aspect of affairs, both at

1 Sir Ralph Maddison, 'Note concerning the helpes of trade,' July I623. Add. MSS. 34324.

Seeley, Growth of British Policy, vol. i. p. 248 : 'Except in Ireland the wars of Elizabeth were to her people almost like peace . . . within the country there were few signs of a state of war ... nor were the pursuits of peace suspended. . . . The naval war, so far from checking the development of the nation, was the very ferment which promoted it,' \&c.

The trade policy of James I. 
home and abroad, that some meaning can be read into the ever increasing economic confusion of the period. These were the underlying causes of the difficulties of the time; but their importance was magnified in England by the failure of the government to grasp the fact of their existence. It was impossible to apply the theories of the sixteenth century to the conditions of the seventeenth. This fact was only learned slowly and painfully, and the lesson was not fully driven home until the chief industry of the country had been jeopardised. It must be said in justice to James, that if he did not understand the difficulties of the time, neither did his ministers, nor could any agreement herein be found among the practical men of the time.

The changes to which reference has been made may be summed up as the after-effects of the discovery of the New World and of the Reformation. The economic importance of the Reformation at this period lies in the mingling of the nations and in the readjustment of the map of Europe which resulted from it. The wars of religion gave birth to a nation destined to take a leading place among the commercial nations of Europe and to be throughout the seventeenth century England's most formidable rival. ${ }^{1}$

The immediate impulse given to commerce and enterprise of all kinds by the discovery of the New World was enormous. Besides this, there were also after-effects which, though more slow to make themselves felt, were equally important. Among these were the changes consequent on the increased supply of precious metals from the American mines. The first quarter of the seventeenth century is remarkable as being a period of currency disorder and frequently recurring monetary crises throughout Western Europe. England did not escape among the nations, but rather suffered more acute

1 Th. Rogers, Industrial and Commercial Hist. of England, p. 89. Indirectly as well as directly the wars of religion \&c. furthered the rise of the Dutch as a commercial nation. 'Flanders was ruined by Alva, the Spanish Inquisition, and the wars of religion. But the ruin of Flanders was the making of Holland.' 
and longer periods of currency disturbance than were experienced on the Continent. For this the action of the Crown towards trade was partly accountable.

Under Elizabeth a definite course of trade policy had been formulated and pursued with considerable success. The Elizabethan trade policy was part of the general scheme of an imperial policy. Trade was encouraged and developed because thereby the power and the wealth of the nation would be increased. The ideal which Elizabeth and her ministers had in view was the building up of the nation in strength and wealth so as to render her secure against foreign invasion. Trade was to be encouraged only so far as it served this end. Thus such industries as fostered the growth of a population strong in numbers and physique were regarded with favour. Above all it was important that trade should be so regulated as both to swell the custom revenues and to supply the country with a store of gold and silver; for the precious metals represented wealth and power in the eyes of Elizabeth and her advisers. This was the keynote of the trade policy of Western Europe in the sixteenth and early years of the seventeenth centuries, and the frequent wars of the period gave it some justification. At the close of her reign a great advance in the trade and commerce of the nation had taken place. But in this as in other matters Elizabeth left a legacy of difficulties to her successor, and James unfortunately was little fitted to cope with them.

The Elizabethan policy was adopted by James and his ministers, and followed more or less consistently throughout the reign. That it was not wholly successful is due to the fact that it was not pursued with firmness or insight. Many vacillations and deviations occurred owing to the needs of the king's purse, and to the vagaries of his foreign policy, as well as to James's characteristic weakness of purpose and want of decision.

James not only had little understanding of the economic conditions with which he had to deal, but seldom directed his full attention to these matters, other interests and difficulties 
taking always a more prominent place in his mind. Among these was the all-important question of the Crown revenue, which even at the beginning of the reign was insufficient to meet the ordinary demands made upon it. Elizabeth, by exercising extraordinary parsimony, had only just managed to live within her means, and James's reckless extravagance soon led him into debt.

Other difficulties, which had appeared of only slight or temporary importance under Elizabeth, assumed more formidable dimensions during James's reign. Chief among these were the scarcity of the currency, the pressure of foreign competition, and the abuses which had grown up in the internal regulation of trade.

The reign of James I. covers one phase of the struggle against the Dutch for commercial supremacy. In the struggle against foreign competition little assistance was given by the Crown. James in framing his foreign policy was guided by personal motives rather than by national motives, and, as he did not comprehend the importance of the latter, he did not scruple to sacrifice trade interests in the pursuance of his own ends. ${ }^{1}$

\section{II}

The condition of trade at the accession of James I.
In spite of the fact that during Elizabeth's reign great expansion of trade had taken place, at the opening of the seventeenth century trade and industry were in a very unsatisfactory condition. The causes of this decay must be sought in conditions at home and abroad.

The war with Spain had closed the markets of Spain and

1 An example of this occurred early in the reign, when, after the treaty with Spain was arranged in 1604, and trade with Spain was re-established, English merchants in Spain were maltreated at the hands of the officials of the Inquisition, and though many complaints were made, James would not take active steps for their assistance, not wishing to risk a rupture with Spain. The treaty had the important indirect effect of bringing about the truce between Spain and the Low Countries in 1608 , by which the Dutch were freed temporarily from the pressure of war, and so enabled to devote their energies to the expansion of their trade, thus becoming more formidable rivals of England. 
Flanders against English goods, while the edict issued by the Emperor at the instance of the Hanse towns forbade the importation of English goods into the Empire. This closing of foreign markets, moreover, had most important aftereffects in leading to the manufacture abroad of goods formerly obtained from England, and thus when commerce was re-established with Spain and the Empire, English merchants found a diminished demand for their goods, and the danger to English trade of foreign competition was heightened.

At home, trade and industry were suffering from the oppressive restrictions and regulations imposed on it by the great companies and other patentees. The plan of providing machinery for trade regulation which should supersede the decayed gild organisations, by conferring exclusive trading privileges and supervisory rights on companies of merchants and private persons, had been adopted by the Tudors and Elizabeth. In this way an intricate system of trade regulation had been developed; but it was one which admitted of great abuses; for the Crown claimed absolute right of conferring patents as it seemed good, and the patentees, within the limits of their charter, had absolute and exclusive powers.

The rights granted by the Crown under letters patent were of three kinds :

(a) Rights of supervision: e.g. monopoly of fines for alnage, licensing of alehouses, \&c. Patents of this kind were numerous, and were capable of being turned to great profit. These were frequently held by noblemen and Court favourites.

(b) Exclusive privileges of manufacturing or of trading in certain articles : e.g. patent for glass-making, silver thread, \&c. In this way, it was pretended, trade and industries could be placed in the hands of those persons best fitted to carry them on, while protection for new processes of manufacture and new trades was also afforded.

(c) Exclusive rights of trading with foreign countries, or 14 
along certain routes. These were granted to companies of merchants. The foreign trade of the country was thus practically divided between a few great companies who, trading under charter from the Crown, not only jealously excluded outsiders from partaking of their trades but also prevented them from obtaining admission into their fellowship. The enterprise and internal regulation of the trade was entirely in their hands, and with them rested also the burden of protecting the interests of the trade abroad.

A distinction may be drawn between the purely commercial trading companies-e.g. the Merchant Adventurers, Eastland \&c., composed of merchants trading separately, but under regulations of the company-and the associations of adventurers, generally conducted on joint stock principles for the purpose of opening up more distant trades, discovery of new lands and planting of colonies \&c.

Elizabeth, moved partly by financial motives, had largely increased the number of monopolies, to the profit of the Crown and the recipients of the patents and to the damage of the trade of the country. Accordingly an outcry was raised against the monopolists in 1597. In I601 the House of Commons took up the matter, and Elizabeth consented to withdraw the most obnoxious of the patents. The removal of the remainder was the question agitating the Commons and a certain section of the merchant class at James's accession. The matter was represented to the king in a memorial of grievances addressed to him in May $1603 .{ }^{1}$ The king responded by issuing a proclamation annulling all patents of monopoly granted by Elizabeth. How little James really had the matter at heart is evidenced in the fact that no steps were taken for enforcing the proclamation, and that soon afterwards he had granted a new patent to one of his Scotch favourites. ${ }^{2}$ The only notable instance of surrender of charter was that of the Levant Company. There were other reasons for this. The Commons followed up the king's proclamation

1 D. S. P. Jac. i., May 1603 .

2 Patent for collecting fines of alnage of new draperies to the Duke of Lennox. 
by introducing a Bill in April 1604 'For all merchants to have free liberty of trade into all countries as is used in all other nations.' The discussion of the committee ${ }^{1}$ appointed by the Commons to consider the Bill, and the evidence given before them, throws much light on the condition and distribution of trade.

This Bill was directly aimed at the overthrowing of the privileges of the great companies; among these the two most oppressive in their regulations were shown to be the Merchant Adventurers and the Muscovy Companies. For the present these were, however, powerful enough to hold their own.

The feeling in the Commons against the companies ran high and the Bill for liberty of trade was passed with a large majority, 'scarcely forty voices dissenting.' The Lords, however, demanded a conference on it, and the Bill was shelved. It was revived in a modified form in the following session, and, as a Bill providing liberty of trade with Spain, Portugal and France, received the royal assent in May 1606.

The experiment of opening the trade to all outsiders was tried in the Levant, and in the trade with Spain and the Archduchy. The Levant Company had been reorganised by Elizabeth, who had granted them the monopoly of the Venetian and Turkey trade, in return for which the company paid to the Crown 4,000l. a year. At the time of James's accession the Levant trade was in a bad way, and the payment to the Crown was in arrears. After the surrender of their charter it was thrown open by the king, subject only to an imposition of $5 s .6 d$. per cwt. on currants. The old company still continued to trade. Difficulties soon arose owing to the competition of the East India Company, and the precari-

I C. J. vol. i. p. 253. 'There was a great concourse of Clothiers and Merchants from all parts, and especially of London, who were so divided as that all clothiers and all merchants of England complained of engrossing of trade and restraint of trade by rich merchants of London, and of the London merchants three parts joined in the same complaint of the fourth part, and of the fourth part some stood stiffly for their own companies, yet repined at other companies.' See Gardiner, Hist. of England, vol. i. p. 187 . 
ousness of their tenure of privileges in the dominions of the Grand Signor, and in 1605 the disorder in the trade was so great that the merchants petitioned for the reorganisation of the company. Under the auspices of Salisbury and Popham a company was again formed in August 1605, which was open 'to all merchants in general or to as many as shall be willing to deal there upon equal and reasonable payments and conditions.' The company was to be under the control of twelve commissioners chosen by the merchants.

A second experiment to render trade free from the regulative tyranny of a chartered company was made in the Spanish trade, which was re-established after the treaty of I604. At first a company on the same plan as that of the new Levant Company was formed at Popham's suggestion, but the Commons, having examined the patent, declared themselves dissatisfied with it, and it was revoked by the king in 1606, when the Act for liberty of trade with Spain, France and Portugal was passed, and the trade thrown open to all. The lack of organisation among the English merchants in Spain soon brought them into difficulties; they were powerless either to defend their property and persons against the Spanish authorities and officials of the Inquisition, or to induce James to take active measures for their protection. The trade with the Archduchy was opened also by the Act. Here the merchants in their attempts to run the Dutch blockade on the Archduke's ports, fell victims to the Dutch, and in spite of their petitions to Cecil obtained no redress. James would not risk a rupture of his alliance with Spain, and did not dare take up a hostile position towards the Dutch.

These two experiments argued in favour of company trading. So long as the burden of protecting the interests of the merchants and furthering the trade abroad was held to rest on the merchants themselves and not on the Crown the company system could not be dispensed with. The weakness of the system lay in the difficulty of preventing the companies from abusing their privileges. 
Other matters intervened to divert the Commons temporarily from their attack on monopolies : among these were the settlement of the Union with Scotland, ${ }^{1}$ and the question of impositions. The dispute on the subject of impositions brought the affairs of the Levant Company again into prominence. The judgment for the Crown in Bates's case had been followed by the issue of Cecil's Book of Rates by which impositions were multiplied and systematised. The outcry raised indicates the importance of the constitutional principle involved rather than the extent of the injury done to trade. ${ }^{2}$ When the Commons revived the attack on monopolies in 1614, it was also not merely on economic grounds that they opposed them, but they raised the constitutional question of the king's right of issuing patents injurious to trade. In spite of their remonstrance the Company of Merchants Trading to France, incorporated by the king in $161 \mathrm{I}$ in contravention of the Act of 1606 , was maintained. The dispute on the question of monopolies and impositions led to the dissolution of Parliament.

During the period of the king's personal rule, another experiment was made to break down the restrictions under which trade suffered at the hands of the companies. This was done in the interests of the cloth trade, and aimed directly against the Merchant Adventurers Company, who in consequence suffered temporary eclipse. The attempt failed and the failure was most disastrous in its effect on trade. It

1 In the discussion of the commercial clauses of the Union with Scotland the Commons shifted from their standpoint of liberty of trade. National jealousy and dislike of the Scotch inclined them to listen to the Merchant Adventurers and other great companies, who urged that complete liberty of trade would mean ruin for the English merchants. The king desired complete commercial equality between England and Scotland. His speech to Parliament, I607, on the subject is interesting: "And whereas some may think this Union' will prejudice some townes and corporations, it may be that a merchant or two out of Bristow or Yarmouth may have rool. less in his packe. But if the empire gaine and become the greater, it is no matter. You see one corporation is ever against another, and no private company can be set up without some loss to another.' (Somers' Tracts, ii. p. 133-4.)

${ }^{2}$ For a full discussion of the subject see Gardiner, Camden Soc. vol. Ixxxi. and Hall, The Customs Revenue of England. 
is interesting inasmuch as it was the only instance of a direct attempt on the part of the Crown to combat the foreign rivals of English trade. In order to explain the circumstances under which the experiment was made and the causes which led to its failure a survey of the previous history of the cloth trade is necessary.

\section{III}

The cloth trade
Cloth was the staple industry ${ }^{1}$ of the country and the chief article of export, but though the processes of manufacture and the standard of the material produced had been much improved under the influence of the alien immigrants ${ }^{2}$ introduced for this purpose by Elizabeth and by James also, the final processes of dressing and dyeing were carried on abroad. The craft of dyeing was practised in England, but not for the best cloths, and such of these as were exported found no sale. ${ }^{3}$

The monopoly of the export trade to France, the Low Countries and Upper Germany was in the hands of the Merchant Adventurers Company, and the greater part of their export trade was in unfinished cloth and raw materials.

Under Elizabeth a feeling of hostility to the Merchant Adventurers Company at home was already aroused by the harshness of their regulations within the trade, and by the jealousy with which they guarded their monopoly against outsiders. Abroad they had to contend against the opposition of the old Hanse League (whose glory was departing) as well as against the competition of the Dutch and other foreign merchants.

1 The cloth industry was chiefly carried on in these districts : (a) Kent, where broad cloths and mingled cloths of dyed wool were made. (b) Eastern counties, where long whites (i.e. undyed cloths), plunkets and coarse cloths were made. (c) Gloucestershire and western counties, where whites, plunkets and red cloths were produced. (Statute Book, 4 Jac. I, c. 2.) In all these districts colonies of Flemish, Dutch and Walloon artisans existed.

2 Cunningham, Alien Immigrants, ch. iv. v.

3 This was repeatedly urged by the Merchant Adventurers in defence of their export of white cloths and raw materials. 
The company was attacked on both sides at once. In 1597 the Emperor, at the instance of the Hanse towns, issued an edict forbidding the import of English cloth into his dominions. Hamburg, which had been the company's headquarters, ejected them and tried to form a league with the other Hanse towns to keep them out. The stoppage of trade which ensued was extremely serious to the company. Their enemies at home took the opportunity to press for its dissolution. ${ }^{1}$ The clothworkers, weavers and dyers joined in this outcry. The interests of the company were obviously not identical with those of the industry.

In I60 I Elizabeth deprived them of a part of their monopoly by throwing open the Elbe and Weser trade. The interlopers made Stade ${ }^{2}$ their port, and many of them visited the inland fairs of Frankfurt, Augsburg and Nuremburg.

This was the position of the company when it was attacked by the Commons in 1604. The Fellowship of Trinity House came forward in its defence, and demonstrated to the House how much the naval service and shipping of the country had benefited by the trade of the Merchant Adventurers. This turned the scale in their favour at home for the time, and abroad also the prospects of the company improved. The citizens of Stade, disregarding the imperial edict, invited them to make their head-quarters in their city. The Hanse towns were still in league against them, and even sent ambassadors to Jamcs in $1603-4$ asking for licence to export 50,000 cloths yearly from England. This demand was summarily refused. Another embassy in the following year having proved equally unsuccessful, Hamburg began to repent of its decision and to negotiate for the return of the Adventurers. In 1607 they received the Emperor's sanction

1 The 'thin end of the wedge' had already been inserted by a licence to the Earl of Cumberland by the Queen for the yearly export of 2,000 cloths-a right which was promptly ' sublet ' to merchants. The company complained in vain of the overlapping of their patent.

2 See Ehrenberg, Hamburg und England, pp. 2 I I-12. Stade was situated a little further down the river on the opposite bank from Hamburg. It was through out this period a thorn in the side of its neighbour.

N.S.--VOL. XIII. 
for their settlement in Stade and many privileges for the regulation of their trade. The company now at last found itself replaced on its old footing; but its power and wealth had been much reduced by outside competition and by the consequent disorder of trade.

In 1609 the Hanse towns made one last effort against the English Adventurers. By an imperial edict they were empowered to lay an embargo on the Adventurers and their goods. Lübeck and Hamburg attempted to carry this into effect ; reprisals on the part of the English followed. Settlement was slow to be brought about. The gravity of the situation for the Merchant Adventurers was so great as to make them seriously consider a proposal of Christian IV. to settle their staple finally in Denmark. At last, in June I6I I, Hamburg made overtures to the company inviting them to return there; and the company decided to leave Stade and establish themselves at Hamburg. Here the struggle between the English Merchant Adventurers and the Hanse towns ended. The company were soon in trouble again, but in another quarter.

In spite of the war with Spain, the Dutch' were steadily becoming formidable rivals of the English in the cloth trade. In I609 a nine years' truce was concluded with Spain, and the Dutch, no longer hampered by war, were free to devote all their energies to the advancement of their commerce and industries. Besides the encroachment of the Dutch on their trade, the company met with a serious rebuff in their export trade to Flanders.

In April 1612 the Archduke issued an edict forbidding the import of all English cloths except white cloths, and those were only to be permitted to pass through Antwerp instead of Dunkirk, the port chiefly resorted to by the English. This edict Trumbull, the English Resident, declared to be an attack deliberately aimed at English trade which demanded

' Cf. Battie, Merchants' Remonstrance. 'There is no greater enemy to trade than war, be it in what country it will, our neighbours the Hollanders excepted, who by so long habit of war seem to make a trade of it.' 
instant action. Sir Thomas Lake argued with reason that the export of raw materials, wool \&c., by the Adventurers and others had furthered the making of cloth abroad and lessened the demand for English cloth. Trumbull, in order to urge the Privy Council to action, had inquiries made into the comparative English exports and imports to and from the port of Dunkirk. The report ${ }^{1}$ is interesting on account of the list of articles and quantities given, and, if correct, proves an alarming excess both in quantity and variety of imports cver exports.

The Privy Council was slow to act, in spite of the urgency of the matter. ${ }^{2}$ This was partly owing to Salisbury's death. Trumbull's papers had been sent to him, and seem to have been temporarily overlooked. Trumbull wrote again in 1612: 'Your Lordship cannot but well understand how

1 See Cotton MSS. Galba, E. i. fol. 344. 'Declaration of the manufactures of these countries [i.e. dominions of the Archduke : and other manufactures carried out of the haven of Dunkirk to the realm of England from May I, I6IIOctober I, I6 I I.

' Total value of goods exported to England, 299,521l. 15s. $8 d$.

' Total value of goods exported to all other countries in the same time, 137,304l. Is. $4 d$.

'Total value of merchandizes conveyed into Dunkirk from England in the same time, 84,832l.' (The list contains various kinds of cloth only, and 'is followed by a Memorandum, that all Bayes and somme of the perpetuanos, durances, and coloured kersies are put directly towards Italy without being spent in the Archduke's countries.')

- Ballance. The manufactures of these countries and other merchandizes doe amount in Flemish money to 5,299,321. 1 $5 s .8 d$.

- The Summe of that which England spendeth more than all other countries, 162,017l. 14s. 4 d.

'The Summe of that which the merchandize of these countries doe amount more than those of England, 55,319l. ros. 8d.'

'See Lansdowne MSS. 152, fol. I75, 'Sir Lionell Crawford [sic, ?Cranfield], his ballance of Trade.' This is calculated from the custom books of the Port of London, and covers the years 1605-1614. The figures show an extraordinary increase in the customs after 1611. Taking the years 1605-11 (inclusive) together, he reckoned the average annual excess of imports over exports at $34,366 l$. The excess for the year from Christmas 16I2 to Christmas 16I3 he reckoned at 346,283l. 17s. od. The excess for the year from Christmas 1613 to Christmas 1614 he reckoned at $413,644 l$. 17s. $5 d$.

Compare also statistics of exports and imports at Hamburg for the year 161 I, given in Ehrenberg, Hamburg und England, pp. 354-357. 
much the banishment of our cloth from here doth prejudice the state of England, both for that it may encourage other Princes to do the lyke, and it is verie probable that if this industrious people may soon attaine the true making of fyne cloth, they will undoubtedly' eat us out of all trade and commerce in divers parts of Christendome'-a prophecy which was before long verified. Various suggestions for retaliation on the Archduke were made. ${ }^{1}$

Meanwhile at home things were going badly with the company. Complaints against them on account of their oppressive dealings with the clothiers and weavers \&c. were numerous; they had to face the hostility also of the numerous interlopers and the Company of Merchants of the Staple, who, although much decayed in wealth, still had many supporters. The prospect of home trade was bad. Distress in the clothing districts caused by the stoppages in the export of cloth was increasing, and actual monetary scarcity prevailed.

The problem of the balance of trade occupied the minds of statesmen and merchants, for while the cloth trade, which was estimated to form nine-tenths ${ }^{2}$ of English export trade, was being taken from their hands, the amount of imported luxuries was enormously increased.

Matters were at this pass when Cockayne and his associates brought forward a scheme for reforming the cloth trade by remedying the excess of imports and checking the insolence of the foreigner. It was proposed to forbid in the future the

1 See Harl. MSS. 295, fol. 71. ' Cloth is the chief manufacture of England, and Lawnes and Cambrics of the Archduke's dominions, therefore the King should banish lawns and cambrics.' The Archduke, it is estimated, by his edict lost at the rate of 7,000l. per annum, but within a year he repaired that revenue by granting a'passport to a private man for the bringing in of 2,000 whites, for which double licence was paid. "His majestie by the banishing of Lawnes and Cambrics shall lose 5,000l. per an. (which is paid for the custom and imposition). But the revenue may be made up with treble so much if his Majestie wilbe pleased to observe the same course for the dispensing with the coming in of Lawnes and Cambrics, viz. after they have been banished four months, to grant a license to a private man for the bringing in of 25,500 pieces. The banishing of Lawnes and cambrics will so gawle the Archduke and his subjects,' \&c. . . .

2 See 'Sir Lionell Crawford, his ballance of Trade.' 
export of undyed and unfinished goods and of all kinds of raw material; to carry on all the processes of cloth-making within the country and to export only finished goods. The project is set forth at length in a tract entitled ' The Benefitt which will redound to your majestie and the commonwealth by this new trade of clothing.' A great increase of customs was promised to the king, and it was hoped that many thousands of poor people would be set on work. The promoters undertook 'at their own means' to set up the trade of clothing in forty cities and borough towns. ${ }^{1}$

The plan was eagerly taken up by the Privy Council and was seriously considered by ministers and by the king himself. The scheme in itself was no new one, but it was unfortunate that it found sufficiently powerful supporters to push it at a time when the trade was in a critical condition and unable to bear the strain necessary for its successful execution.

The notes of some of the debates in Council preserved among the Cæsar papers cover the rise and fall of the scheme. The arguments for and against the new company are interesting and the notes show that a real attempt was made to sift the question thoroughly before action was taken.

The advice of leading merchants and of various companies was asked. ${ }^{2}$ The East India Company certified their opinion (January 1614) 'that the realm shall receive more benefit by dressing of clothes at home than by sending them

1 See Casar Papers, Add. MSS. 14027, fol. 27I. 'It is intended that not only all sort of clothyers, but all others whomsoever shall from tyme to tyme have free liberty to come and peruse the work at their pleasure whereby they may set the same up when and where they please.'

It was proposed that the king should assign to them, for the furtherance of the project, "the third part of money to be raysed by the sales of the lands tenements and hereditaments payable to his Majesty.'

${ }^{2}$ Add. MSS. 14027, fol. 263. The question of the legality of the scheme to export dressed cloths in contravention of the charter of the Merchant Adventurers Company was disposed of by Sir E. Coke, who was an ardent supparter of the scheme, thus : the company in exporting only white cloths and raw materials had not fulfilled their charter, and ' a charter gotten and not pushed loseth his force for things transportable for the Commonwealth's good.' 
unwrought abroad.' The Turkey, Spanish and Eastland Companies sent in a certificate to like effect. The French Company answered cautiously that 'if it would not hinder the trade we doubt it would be better to have our cloths dressed and dyed in England.' The Merchant Adventurers were the only company which did not produce a like certificate. Their answer to the Council's inquiries took the form of a petition against the change. They knew better than the others how great was the risk involved and moreover they themselves had much to lose. In answer to the king's question in Council, July 9, 1614, "Will it be profitable to the Commonwealth, if feasible ?', they answered in the negative, alleging that the English workmanship was not good enough, that the foreigners already bought but few dressed cloths, as they wished to set their own people on work; and so on. 'Our merchants find by experience, that, were it not for our white cloths, our coloured would be banished.' The promoters of the new scheme promised a gain of 300,000l. 'Shall for this hope,' it was asked, 'so great a calamity as this cause ill succeeding be ventured upon at this time?' Finally they declared: "The project is not fit for this time and the stop in trade which it will cause will be an inestimable evil to the state. Of the cloths at present dyed and dressed in England many are left on the merchants hands, not a quarter are sold.'

It was of little avail for them to protest, for the new scheme had powerful supporters who had the ear of the Council.

It is stated in a contemporary tract, "Truth brought to light by Time,' ${ }^{\prime}$ that large bribcs were distributed among the king's advisers, viz. to Lord Northampton, Lord Rochester, and to the Lord Treasurer, in order to gain their support.

The clothworkers of Essex, Suffolk, and Norfolk were among the few concerned who protested against the scheme. They alleged that the making of coloured cloths, both in

1 Printed in the Somers' Tracts, vol. ii. 
Essex and in other parts, had only been disused because no salc could be found for them abroad or at home. ${ }^{1}$

The first blow at the old company was struck by the king's letters patent of December 3, 1613, directed to 'Lord Cooke, Sir Thos. Middleton, Sir Lawrence Tanfield, Sir Stephen Somer, Sir George Coppin, and William Cockain Esq.' It was ordained that ' they who undertake to vent dyed cloth and dressed shall not be restrayned but shall have a free trade to all places where now our clothes are vented white.' A new company of Merchant Adventurers was formed. ${ }^{2}$ Cockayne promised to import foreigners to teach the English the better art of dyeing \&c. The city of Stade sent ambassadors, in February $\mathrm{I}_{\mathrm{I}} \mathrm{I}$, to make overtures to the king and to ask for the appointment of commissioners with whom to arrange for trade 'as well in dyed and finished cloths as others.' ${ }^{3}$ This was backed by a grant from the Emperor of privileges to the English merchants trading in the Empire to the city of Stade. Cockayne was therefore justified in hoping to have secured a certain market for the products of his new company.

At first the new company attempted to trade side by side with the old; but it met with no success. Already in 1614 complaints against it were brought before the Privy Council. The Luw Countries had retaliated by issuing a ban against all English cloths, dressed or undressed. Furthermore a serious practical difficulty arose. The company did not produce a good article. No sale at home could be found for it and the merchants were left with it on their hands. The

1 See MS. Egr. 2651, fol. 24. 'Certayne reasons why the Clothworkers Bill should not passe, objected by the clothiers in Essex.' 'We cannot vent nothing near all our clothes except we may sell them to the Merchant Adventurers, who will by no means buy them unless they may transport them undressed as heretofore. ... Wherefore we pray that due consideration be had hereof, for yf our clothes lie on our hands unbought we must be driven to make much losse to the great hindrance of the clothiers and the poore of this Country.'

2 This new company was not incorporated by charter till 1615 .

s A commission of ten merchants for this purpose was appointed in April 1614, among whom were Sir Thomas Lake, Alderman Cockayne, W. Garraway, W. Harrison, Sir Daniel Dun, \&c. Add. MSS. 14027. 
new company in defence claimed that they had not had sufficient time, and that members of the old company were trying to ruin them. It was also contended that until the craftsmen had learnt the processes of finishing cloths the company must be allowed to support itself by a licence to export 'whites' in limited quantities. The old company, who refused to join them, was dissolved by the king in 1615 , and a new charter was issued incorporating Cockayne's company. The conditions under which the patent was granted were, that the new company should transport within three years 36,000 cloths dyed and dressed, ${ }^{1}$ and after three years it should endeavour to dye and dress all cloths. In the mean while it had leave to transport 30,000 'whites,' ${ }^{2}$ yearly. It inherited all the rights and privileges of the old company, and was further permitted to stretch cloths 'as they doe beyond the seas and to bring into England such stranger workmen as they think fit.' 3

In the king's message to the Privy Council (January I4, 16I5) he provided that if the company would perform the 6,000 dyed cloths in the first year \&c. they should be cherished. If not, then Cockayne should be questioned. If the cause be want of stock, the old company should be enforced to assist for the public good, or if by let abroad, this should by all good means be removed. If to the Council's impartial eye, the work should seem unfeasible they should alter it to the king's best profit. Of the king's immediate advisers Sir E. Coke ${ }^{4}$ was a keen supporter of

1 Viz. in the first year (June 24, 1615-June 24, 1616), 6,000 cloths; in the second year (June 24, 1616-June 24, 1617) 12,000; in the third year (June 24, 1617-June 1618) 18,000.

2 Subject to the payment of $2 s$. $8 d$. per cloth to the Earl of Cumberland who still maintained the right granted by Elizabeth.

${ }^{3}$ For arguments against the incorporation of the new company, see Cotton MSS. Galba E. 1, fol. 287. Letter signed Ric. Gore, January 18, 1615.

- Coke had only been admitted to the Privy Council in the autumn of 1613 . He was disgraced and suspended from the Council June 1616. The king in his message to Council, January 14, 1615, stated ' that my Lord Cooke held him in conference that the work [i.e. the dyeing and dressing of cloths] was very profitable to the state, and feasible as he thought, but in a little time.' See Casar Papers, Add. MSS. 14027, fol. 262 et seg. 
the plan; Bacon approved the idea but 'had always doubted the ability of the company to carry it thro'; Cranfield was doubtful from the beginning and seriously opposed the granting of the charter. In the meantime the Dutch had set up looms and were determined to ruin English trade. ${ }^{1}$ Bacon, on being appealed to by the king, February 25, 16I6, wrote his opinion of the new charter: ' $I$ fear this feeding of the foreigner may be dangerous, for as we may think to hold up our clothing by vent of whites till we can dye and dress, so they (I mean the Dutch) will think to hold up their manufacture of dyeing and dressing upon our whites until they can cloth.' The only remedy he could suggest for the daily increasing distress was the enforced sale of cloth instead of silk. ${ }^{2}$ (September I6I6.)

In October of the same year Bacon openly joined the throng of opposers and set forth his reasons 'why the new company was not to be trusted nor continued with the trading of cloth.' ${ }^{3}$

The affairs of the new company went from bad to worse and the cloth trade was completely disorganised. The Dutch would not yield. At about the same time a bankruptcy on a large scale of a Scotchman in Prussia who had in his possession English goods to the value of $80,000 l$., and another failure for a greater sum, caused a panic among merchants. ${ }^{4}$ Cockayne, among others, was involved in this loss. On January, 19, 1617 , the new company gave up their charter and the old company was reinstated. ${ }^{5}$ Though the

1 See Lansdorme MSS. 152, fol. 273, 'Humble Remonstrance of New Company of Merchant Adventurers,' September i I, I6I6.

2 'Your Majesty shall supply outward vent with inward use, specially for finer cloths, which are those wherein the stand princ:pally is, and which silk wearers are likest to buy ... and your Majesty shall blow a horn to let the Flemings know your Majesty will not give over the chase. Again the winter season coming on is fittest for wearing cloth, and there is scope enough left for bravery and vanity by lacing and embroidery,' and so on. Spedding, vol. vi. p. 73.

3 Spedding, vol. vi. p. 73.

4 Carew Papers, p. 70 (Cam. Soc. Pub. vol. Ixxvi.).

5 As an example of the minor hindrances in the way of trade, it is instanced among the charges of extortion against Suffolk at his trial in 1619, that he 
restoration of the old company silenced the complaints temporarily, it gave no immediate relief to the situation. The injury done to English trade was beyond the remedy of king or ministers. While England had fallen back a pace the Low Countries had taken a stride forward. Had it not been for the fact that the Low Countries were soon again involved in war, England would not perhaps have found herself able to hold her own against them. During the nine years of truce (1609-1618) the Low Countries had outstripped England in the cloth trade, and in the India trade competition was keen. The failure of the scheme by which James had hoped to alter the whole course of the cloth trade to the advantage of England was not only disastrous economically, but also politically, in damaging the prestige of England.

The cloth trade received another serious rebuff in 1622 , when a Pragmatic was issued closing the ports of Spain and the Archduchy against English cloths. This was renewed with more stringent orders for its enforcement in February 1623.

The decay in the cloth trade caused widespread distress in the country districts and gave rise to outbreaks and risings. During the years $1622-23$ the trade of the country was almost at a standstill.

The condition of trade and the scarcity of money had been the subject of a debate in the Commons in 1620. ${ }^{1}$ The dissolution of Parliament followed shortly after and prevented the members from attempting to institute any remedial measures.

In the summer of 1622 a sub-committee of the Privy Council was appointed to inquire into the causes of the deadness of trade. The report ${ }^{2}$ of this committee set out six general causes, viz. "the making of cloth and other draperies in foreign parts in more abundance than in former

received 3,000l. from the Merchant Adventurers to suffer their renewed charter to pass, which could not be despatched before by reason of his (Suffolk's) opposition. See Speduing, vol. vi. p. 37 .

I See Parl. Hist. vol. i. p. 1192.

${ }^{2}$ See D. S. P. Jac. 1, vol. cxxxi., June 22, 1622, and Stowe MSS. 554, fol. 46 . 
times, (the foreigner) being enabled thereto chiefly by wools exported from England and Ireland and Scotland; the false and deceitful making of cloth at home and the heavy burdens imposed on it whereby it is made so deare to the buyer; the present state of the times by reason of the warrs of Germany have interrupted the passages (of trade); the policy of the Merchant Adventurers who bring upon themselves the suspicion of combination in trading, and the like policies of other merchants who are not willing to extend themselves in this time of extremity to take off the cloth from the hands of the clothiers; the scarcity of coyne at home and the baseness of forrayne coynes; the want of means of return for our merchants, ${ }^{1}$ and the little wearing of cloth at home.' Remedies on each point were suggested.

This preliminary inquiry was followed by the appointment of a standing committee for trade on October 19, 1622. ${ }^{2}$ The articles of inquiry directed to the commissioners were exceedingly wide, and embraced every branch of trade. Besides dealing with the scarcity of currency, the fisheries \&c., and examining into the details of trade regulation, the com. missioners were directed to consider the question of trade policy in general. Searching inquiries were ordered to be made both in the country districts and in the towns where distress was rife.

Among the suggestions for remedy made to the commission the most interesting is that of Walter Morrell for the reorganisation of the cloth trade. ${ }^{3}$ His plan was that a charter should be granted to each county (of the clothing districts) empowering each to make ordinances and regulations

1 'Especially of the Eastland Company, which discouraged them to carry out cloth thither because they can neither sell for ready money nor barter for vendible commodities.'

2 The appointment of the standing committee was regarded as a sign that no new Parliament would be called for the time being. See $D . S . P$. Jac. 1, vol. clxxxii., November 2, 1622 ; Sir F. Nethersole to Carleton.

' See Add. MSS. 34324, fol. 201, 'A Redy Course propounded for the establishing and certaine settling of the Manufacture of all manner of Draperies to be brought under government for the true and exact making of them,' by Walter Morell.

15 
as time and occasion might require. The Lord-Lieutenant of the county was to be ex officio master of the corporation, the deputy-lieutenants to be wardens, and the justices, assistants, of the corporation ; in addition to these a selected number of 'gentlemen yeomen and artizans in any trade of the said county,' chosen by the master, wardens and assistants, were to be associates of the corporation.

The scheme was given a trial in Hertfordshire (for which a charter was granted in 1624), and in Devonshire (in 1626). ${ }^{1}$

When Parliament met, in February 1623 , it was moved by Coke that 'there was a great want in the value of that which is the life of the kingdom, viz. trade, and the want of vent of native commodities, which brings a great want of money and disvaluation of our native commodities : and that it would be an excellent work for Parliament to remove these impediments.' A select committee was chosen for this business. It was reported that the two charters which were of the greatest hindrance to trade were those of the Merchant Adventurers and the Eastland Companies. The commissioners appointed under the Privy Council had already been inquiring into the affairs of the Merchant Adventurers Company, and the results of their inquiry were reported to the Parliamentary committee.

It was alleged that the Merchant Adventurers Company only numbered 180 members and that in the past year only 35,000 cloths had been exported by them. It was urged that for the encouragement of trade anyone should be free to enter on payment of five marks. ${ }^{2}$ The company was ordered to submit their charters and account books to the examination of the committee. The charters, especially that of 1617 , granted in the reaction following the failure of Cockayne's new company, were found to be most prejudicial to all merchants and to trade in general. Under the charter of 1617 , it not

1 See Dict. Nat. Biog. 'Morrel (Hugh).'

2 On the other hand it was argued: "To add more persons to the Merchant, Adventurers now would be to put more sheepe into one and the same pasture which is to serve them all.' See Cæsar's Notes, Add. MSS. 34324, fol. 195. 
only enjoyed an absolute monopoly of the trade, but also an unrestrained right of imposition, and the cloth trade was as heavily burdened by them as by the imposts under the Book of Rates. The condition of the cloth trade under the Merchant Adventurers Company was merely an illustration of the prejudicial effects of monopolies and impositions on the commerce of the realm. It was urged by Sir E. Sandys that their right of pre-emption and export of cloths should be abolished.

In spite of the statute against monopolies passed in 1624, the Merchant Adventurers retained their monopoly, under certain conditions, viz. they were allowed the sole right of exporting cloth on condition that they bought it up and did not leave it in the clothiers' hands, and their right of impositions was taken from them.

\section{IV}

In the East India trade the English followed on the heels of the Dutch and the Portuguese. Elizabeth had incorporated the East India Company by charter in 1600 . At the time of The East India Trade. James's accession it had made its first voyage successfully. The adventurous character of the trade, the magnitude of the gains to be made and of the risks to be incurred, attracted the best blood among the merchant class. The distance and the dangers at this time made the rivalry of interlopers less serious than in other trades or at later times. At first the Dutch and English made common cause against the Portuguese, whom they eventually succeeded in ousting; then with the field to themselves, and while nominally at peace, each did their best to spoil the trade of the other.

The East India Company had also enemies to deal with at home. These were $(a)$ the members of the Levant Company, who complained that they had ruined their trade; (b) the general public, who regarded with dislike the export of bullion to the East. By the king the East India Company was regarded with favour. 
In 1609 , after four voyages had been made, three of which had proved successful, the company applied to the king for a new charter. The king granted them an absolute monopoly of the trade with the East Indies for ever. To commemorate the event, the largest ship yet built was constructed, and was christened by the king, 'The Trades Increase.' So far factories had been established only at Acheen in Sumatra and at Bantam in Java. In the years $1609-1616$ the trade rapidly increased. In 1612 an attempt was made to trade with the mainland; in the following year Captain Best obtained the assent of the Great Mogul to articles for permission to trade and establish factories in Surat, Camboya, Ahmedabad, or any other part of his dominions.

In 1615 Sir Thos. Roe was sent out by the company as governor. He went also in the capacity of ambassador from James to the Great Mogul and other native authorities. In the five years of his residence in the East, he succeeded in putting the English trade on a firmer and wider footing. $\mathrm{He}$ set himself deliberately to work to make friends with the native authorities, and to oust the Portuguese, against whom in 1616 he declared open war. In this he was assisted by the Dutch. He wrote home in January 1616 that the English are beating the Portuguese back. 'They are beset on every side; the Dutch plant about them and the Persian has banished them.' 1

In July I6I 5 factories were established both on the west and east coasts of the mainland, as well as in Sumatra, Borneo, Java, and Celebes, and trade was being carricd on with Camboya, Pegu, Siam, and Cochin China. This was not accomplished without disagreements and conflict with the Dutch. In the Moluccas the English suffered most severely at their hands, and already in I6I I the Company petitioned Salisbury, the Lord Treasurer, to negotiate with the States on their behalf. This was done, and the States gave the necessary promises; the government was satisfied for the time, but little or no change was made in the position of the English mer-

' See State Papers, Colonial, vol. i. No. 1087. 
chants in the East. Shortly after this, negotiations were opened by the Dutch, who proposed that the English and Dutch should unite together to form one company, with a a joint capital of about i2,000,000l. The commissioners appointed to arrange a settlement of the whole fishing dis: putes were empowered to discuss the matter. The commission ended in nothing, and the matter dropped for the time, but was revived by James himself in the next year (I6I4), but again without result. The leading members of the company; Sir Thos. Roe, Bell and others strongly opposed the plan. It was again brought forward by the Dutch in the weary course of negotiations leading to the unsatisfactory truce of I6I9.

A most important result of Roe's administration was the opening of trade with Persia. Negotiations to this end were begun in 1616 , and a treaty was signed with the Shah of Persia in 1618 , and the trade opened in October $162 \mathrm{I}$, when four of the company's ships arrived at Jask. This extension of trade roused opposition from the Portuguese subjects of Spain already engaged in trade with Persia. James, however, was keenly interested in the trade, and even neglected the com. plaints of the Spanish Government, as well as the outcry made at home against the exportation of bullion necessary to start the trade. ${ }^{1}$ On this point Roe wrote to the king: "If I find by one year's experience more that this trade may bee made by vent of the commodities of your majesties kingdom etc. without greater exports of money or bullion than Europe is able to bear, considering how many ways it bleedeth to enrich Asia, I will confirm in your name the treaty begun.'

Opposit:on arose also in other quarters. The Levant trade, still hampered by impositions on their imports, declared that for the East India Company to open trade with Persia was an infringement of their mono oly. They justified their trade as against that of the East India Company by contending that it did not involve an exportation of bullion, but that

1 See Carew Papers, Camden Soc. Ixxvi. p. 77. Carew estimated that at least $600,000 l$. would be necessary for this purpose. 
they were able to find new markets for English cloth. The question seemed really serious for the Levant Company. They were in 1616 again in difficulties with the Sultan, who had allowed the company's principal factor, Garraway, to be imprisoned there by his Vizier Bassa. They petitioned the king to come to their aid, alleging that 'their trouble ariseth from the robberies etc. committed (as the Turks alledge) by English merchants upon the Grand Signor's subjects in the East,' and so on.' In I6I 7 they complained again that their merchants were so ill-used at Constantinople that they are doubtful 'whether to continue the trade or to relinquish it.'

They saw a further danger of irritating the 'Grand Signor' in the opening of a new channel for the Persian trade. $^{2}$ The East India Company were powerful enough to disregard the complaints of the Levant merchants. The fears of the Levant Company proved to have been exaggerated. In 1619, after Sir Thomas Roe left the service of the East India Company, he entered that of the Levant Company, and resided five years at Constantinople as ambassador. During this time he succeeded in setting the affairs of the company in order and the trade on a better footing. ${ }^{3}$

The years 1617-22 were a time of stiff struggle for the East India Company. The crisis in trade at home may perhaps have influenced the fortunes of the company. The hostility of the Dutch was their main difficulty. Other lesser matters at home contributed to temporarily hamper them. The king, hard-pressed for money, had granted a licence, in January 1618 , to Sir James Cunningham to establish

1 See Carew Papers, Camden Soc. Ixxvi. p. 77 ; D. S. P. Jac. I, vol. xc. 24.

2 See C:ırezu Papers, Camden Soc. lxxvi. p. 77, Letter iii.; D. S. P. Jac. I, vol. xc. 24. Carew writes : 'Since there is such a madness in England as that we cannot endure home made cloth, but must needes be clothed in silk, itt cannot be gainsayed but the silkes bought at first hand is the best husbandry.'

3 Fortescue Papers, No. cli. Camden Soc. N.S. I. Sir Thos. Roe to Duke of Buckingham: 'I have sett in order all their [i.e. the Levant Company's] affaires and revived their trade in such sort that $I$ hope it shall bee both beneficial to the kingdom and to them, and an advance of his Majesty's customs. I have settled the peace with Barbary if it be not shaken again by want of small liberalities to maintain it.' 
a Scottish East India Company. This was in direct contravention of the charter held by the company, and was stoutly resisted by them. The king acceded to their demands, and declared himself willing to annul the licence, but the company had to pay heavily for the concession, by way of indemnity to the Scottish Company. ${ }^{1}$ The final revocation of the Scottish patent was offered as an inducement and reward to the company in the affair of the Muscovy loan. The Emperor of Russia in 1618 sent ambassadors to James, asking for a loan of 100,000 marks for his wars in Poland. James suggested that the Muscovy Company should produce the money. As they were not sufficiently wealthy to bear the whole burden of the loan, they solicited the co-operation of the East India Company. This was arranged, and the two companies further agreed to carry on a joint trade on an equal stock of adventure for eight years. ${ }^{2}$

Meanwhile open hostilities had broken out between the Dutch and English traders in the Spice Islands. In September 16I 8 a list of complaints against the Dutch were drawn up by the company and presented to the king. A joint commission of inquiry of Dutch and English was appointed, and after seven months of discussion a settlement very much to the disadvantage of the English was drawn up, mainly through the instrumentality of the king. A treaty for twenty years was signed July 16, 1619, of which Carleton, English Ambassador to the States, wrote: 'It is in effect but a prorogation of the treaty to a longer and more fitter time.' It was arranged that the two companies (Dutch and English) should share the monopoly of the spice trade, to the English one-third part being assigned, and to the Dutch two-thirds; each company should contribute ten ships for the defence of the trade; a Council of Defence composed of members of each company was to be established; the English company was

1 See S. P. Col. 1618. 'The East India Company thought that the Levant Company ought to contribute to the great charge of calling in the Scotch patent.

2 Ibid. March 27, 1618. Each company was to supply 30,000l. yearly. It was hoped to gain additional trading privileges, both in Muscovy and for trade routes to Persia.

N.S.---VOL. XIIr. 
not to erect forts for its own defence, but to contribute towards the maintenance of those already established by the Dutch. Great dissatisfaction was felt by the English merchants. The treaty was hardly signed at home before hostilities broke out anew in the East. Matters indeed went so badly for the English that the dissolution of the company was talked of. ${ }^{1}$ In the autumn of $162 \mathrm{I}$ another joint commission was appointed. The Dutch were anxious to treat with the king alone, seeing that the treaty of 1619 had been brought about through his influence. To this the English company were strongly opposed. A second treaty was signed in February 1623 , but no settlement was reached on the important question of regulation of the trade. It was the general opinion of the time that the king was moved by considerations of foreign policy in his desire to patch up a treaty with the Dutch. James's negotiations with Spain were breaking down, and the Dutch were again fighting Spain in the Netherlands.

Matters went from bad to worse in the East; not only were the English being driven out of the spice trade, but their trade with the mainland at Surat was threatened by the Dutch. In May I624 the news arrived of the massacre of the English merchants at Amboyna ${ }^{2}$ in the Moluccas. In the following June James concluded a treaty of offensive and defensive alliance with the Dutch. When the English merchants appealed to the king for redress, they found little hope of obtaining even justice. The treaty with James had strengthened the hands of the Dutch. They knew that James would not come to an open breach with the States, and they hoped by temporising to force the English merchants out of the trade. The English company had no choice and a new commission was appointed.

1 See Hist. MSS. Com. Appendix to the Third Report, p. 64 (6). Four papers, 1620 , 'Informations and observations that the East India Company are resolved to have and divide the trade.' The trade is declared to be carried on at a loss to the adventurers. The writer attributed this largely to internal dissensions in the company ; also to a want of protection on the part of the king of their privileges.

2 The massacre occurred on February II, I624. 
The English merchants threatened to give up the trade. The king declared himself willing to help, but did nothing. The merchants pressed him to seize the Dutch ships in the narrow seas until redress was given. This James delayed to do, in spite of his promises. ${ }^{1}$ He offered to become himself an adventurer in the company and to have its ships sail under the royal flag; but to this the company would not consent. ${ }^{2}$ Besides redress for the damage sustained, they desired complete separation from the Dutch.

In October I624 they submitted three propositions to the king. They declared themselves willing to give up the trade with the Moluccas, and to remove their agents 'from Jacatra (i.e. Batavia) and all other places where they have lived under the laws and cruel commands of the Dutch,' on condition (I) that they should be allowed to withdraw quietly and without molestation, (2) that all disputes in future between Dutch and English should be decided by the Council of Defence, appeal from their decision being allowed to the king and the States, and (3) that they should be allowed to erect forts in defence of their factories in other parts and be treated by the Dutch as allies. These propositions with some reservations were agreed to by the States in December 1624. The English company obtained no redress for the damage received at Amboyna. Desultory attempts were made in the following reign to obtain it, but it was not until 1654 that the Dutch granted it. ${ }^{3}$

\section{V}

While in the East Indies commerce was established Plantaduring the reign without any previous attempt to obtain tions.

1 The warrant was signed by Buckingham, October 1624 .

${ }^{2}$ See S. $P$. Col. vol. 1622-24, No. 527. They answered to the king's request that 'they cannot conceive how with his honour it may be done. The condition of partnership in trade being beneath the dignity of a king.' Prince Charles had been allowed to adventure 6,000/. in 1619 .

${ }^{3}$ See Thurloe State Papers, vol. ii. p. 592. Sept. 18, 1654. The Dutch granted 3,615l. ' for the busines of Amboyna.' 
territorial dominion, in the West the plantation of colonies to open up the resources of the land necessarily preceded the establishment of commerce. Companies of adventurers were formed for this purpose, incorporated under royal charter. The crown, as a rule, neither took the initiative in these enterprises, nor shared in the burden of risk and expense.

Attempts were made to obtain foothold in Guiana. In 1609 Harcourt made a voyage thither and took possession of the land for King James, who in 1610 granted a patent to Harcourt and his associates for the discovery and plantation of the territory between the River Amazon and River Dollesquebe (Essequibo). This patent was renewed in I6 3 . The scheme was regarded with extreme disfavour by Spain. The active hostility of the Spanish colonists was aroused by Raleigh's unfortunate expedition of 1617 . A new patent was granted to Roger North in 1619, but was subsequently revoked at the instance of Gondomar. It was not until I627 that Harcourt and North with a patent from Charles I. at last established an English colony there.

The English settlement of Newfoundland dates also from this reign. Newfoundland had been formally taken for Elizabeth by Sir Humphrey Gilbert in 1583. In 1608 a scheme for its plantation was brought forward by Popham, and taken up by Guy and other Bristol adventurers. A patent was granted in I610 to the Earl of Northampton, Guy and many others, merchants of Bristol and London, incorporating them as a company for the plantation of the S. and E. portion of the island, between $46^{\circ}$ and $52^{\circ} \mathrm{N}$. lat. In the summer of the same year, a colony, under the leadership of Guy, was established. The fisheries being already resorted to by West of England fishermen, as well as by foreigners, the exclusive right of fishing was withheld in spite of the petitions of the planters.

The most important colonial enterprise of the reign was that of Virginia. Several attempts had been made under Elizabeth for the settlement of this territory (notably that of Sir W. Raleigh), but without success. 
A new scheme for the plantation of Virginia was brought forward in 1605 by Popham, the Earl of Southampton, Hakluyt, and others, who, besides laying stress on the possible wealth to be obtained, urged that the plantation would offer an outflow for some of the turbulent and indigent population of the country. A patent was granted in 1606 . One of the chief causes of failure in the Elizabethan attempts to colonise had been the want of adequate machinery for the control of the colonists. The patent of 1606 , therefore, contained an elaborate scheme of government. The Crown reserved for itself a royalty of one-fifth of the proceeds of any discoveries of gold and silver mines. The territory granted in the patent was divided between two companies-a West of England compariy, who were to make a settlement in the tract of land lying between $38^{\circ}$ and $45^{\circ}$ lat. N., and a London company, who were to plant their colony in the land between $34^{\circ}$ and $4 \mathrm{I}^{\circ}$ lat. N. The two companies were to plant their settlements at least 100 miles apart from each other.

The northern settlement failed completely at first. The tract of land, later known as New England, was afterwards settled by the Pilgrim Fathers. The southern colony (that of the London company) survived in spite of enormous difficulties. The machinery of government established under the first patent having proved unmanageable and unsuited to the needs of a young colony, a new patent was issued in 1609, in which considerable reforms were introduced.

The king provided, for the encouragement of the colony, that all commodities shipped for the use of the colonists in Virginia ${ }^{1}$ should be freed from custom and all other duties; the monopoly of the colony's trade was granted to the company, and for twenty-one years all goods exported from the colony were to be exempted from all duties beyond a 5 per cent. custom duty.

${ }^{3}$ See S. P., Foreign; Order of Salisbury to Customs officers, May 3, 1609. 
In 1612 an offshoot of the Virginian company established a settlement in the Bermudas or Somers Island. These were granted an independent patent of incorporation in 1614 , and they were empowered to raise funds for their enterprise by means of lotteries, a right which evoked a remonstrance from Parliament in 1614. By the year 1616 the colony in Virginia was established and in a fairly prosperous condition. The initial difficulties of planting the colony were surmounted, and definite attempts were made to plant and foster industries and establish trade. The staple product of the colony was tobacco. The production of this on a large scale was regarded with disfavour both by the London council of the company and by the king. Tobacco being merely an article of luxury, the use of which, though spreading rapidly, was not yet general, it was considered both risky and impolitic that its cultivation should become the staple industry of the new plantation; moreover, it was found necessary in the interests of the settlers themselves to restrict the growth of tobacco. The colonists, finding it their only easy source of gain, were inclined to cultivate it at the expense of corn and other crops. Sir Thos. Dale, whilst governor of the colony, introduced strict regulations to prevent this evil. He provided 'that no farmer or other, who must maintayne themselves, shall plant any tobacco unless he shall yearely manure, set, and maintayne for himself and every manservant two acres of ground with corne, which doing they may plant as much tobacco as they will.' 1 After Dale's departure, these provisions for securing an adequate corn supply were not observed, and the colony in I6I 8 was reduced to a condition bordering on starvation.

The king, besides harbouring a personal dislike of tobacco, had other reasons for disapproving of the importation of tobacco from Virginia and Somers Island. The tobacco trade had formerly been entirely in the hands of the Spanish colonies. The Spaniards had from

${ }^{1}$ See Rolfe, Relation of Virginia, Purchas, 1617. 
the beginning regarded with hostility the establishment of English plantations in America; the development of the Virginian tobacco trade was regarded as a further encroachment on their rights. James, always anxious to keep on friendly terms with Spain, was more than ever ready to pander to Spain, pending the negotiations for the marriage of Charles and the Infanta. James had also another reason for favouring Spanish tobacco in preference to the other, viz., that the Spanish tobacco yielded him better custom revenues. In James's gradual change of attitude towards the plantations, as illustrated in his dealings with the tobacco trade, may be traced the forms of the policy developed more definitely later, of subordinating the interests of the colony to those of the mother country.

The interests of the colony suffered at the king's hands in two ways. The company was directed in 1619 to provide for the transportation of a hundred convicts. The king's order was peremptory, and in spite of remonstrance the company was forced to comply, and the chief share of the expenses of transportation had to be defrayed from the general purse.

The difficulties in the tobacco trade began in the same year. In contravention of the patent of 1609 the custom officers demanded a duty of $\mathrm{i} s$. per lb. on Virginian tobacco. This was nominally the same as that paid on Spanish tobacco, but whereas Spanish tobacco was worth $18 s$. to 20 . per lb., the current price of Virginian tobacco was 3 s. The company appealed to the Privy Council, who decided the case in their favour. In 1620 , however, the king rescinded the Council's decision, and re-imposed the duty of Is. The company was forced to submit, the only result of their petition to the king being a promise to prohibit the growth of tobacco in England for five years. In the following year, I62I, the king made another move, still more favourable to the Spanish tobacco trade. A proclamation was issued limiting the importation of tobacco from Virginia and the Somers Islands to $55,000 \mathrm{lbs}$. The monopoly of the 
Virginian tobacco trade was at the same time granted to Sir Thos. Roe; in the following year it was transferred to other patentees. The company was forced to sell all their tobacco to the patentees, who demanded an additional impost of $4 d$. per pound for garbling. ${ }^{1}$ In the mean time the fortunes of the Virginian company were impaired by other disasters and difficulties. The colony was attacked by the natives in 1622 , and a great massacre took place, and villages, houses, and crops were destroyed. Quarrels had also arisen within the council of the company, which was divided up into factions. ${ }^{2}$ In 1619 Sir Thos. Smith, who had been appointed treasurer of the company by the king, and who had held the post for twelve years, was not re-elected, but Sir Edwin Sandys, an ardent opponent of the Crown in the House of Commons, was chosen in his place. This appointment was regarded with great disfavour by the king. Henceforth a political element was introduced into the relations of the king to the company. Within the company party feeling ran high. The king refused to relax the restrictions imposed on the colonial tobacco trade, and the company addressed a petition on the subject to Parliament. The Commons took up their cause, and the tobacco question was embodied in their list of grievances.

As no redress, however, could be obtained, it was arranged that the whole import of $55,000 \mathrm{lbs}$. should be allowed to the Somers Islands (as that colony was entirely dependent on their tobacco trade), while the Virginian colonists arranged to export their tobacco in increased quantities to Holland. The Privy Council would not agree to this arrangement ; and in the following year a proclamation was issued prohibiting

1 See Cowell's Interpreter. ' Garbling of spice is nothing but to purifie it from the dross and dust that is mixed with it.' In 1620 a commission was appointed who were to draw up orders for the garbling of tobacco before it was exposed to sale. See Rymer, Foedera, vol. xvii. p. 190.

2 See E. D. Neill, History of the Virginian Company of London, p. 413. Letter, Chamberlain to Carleton, July 26, 1624. 'The factions in these two companies (the Bermudas and Virginia Companies) are grown so violent, as Guelphs and Ghibellines were not more animated against one another . . ' \&c. 
the export of any commodity from the colony except to England and in English bottoms. This prohibition was renewed in 1623. This measure marks the beginning of the policy, afterwards developed by the Crown towards the colonies, of making the trade interests of the colonies entirely subordinate to those of the mother country.

Towards the close of the year 1622 , a new scheme for the settlement of the tobacco trade was brought forward by the Lord Treasurer Middlesex. A contract was made, by which the monopoly of the tobacco trade was granted to the Companies of Virginia and Somers Islands free of all charges except the original 5 per cent. duty, on condition that onethird of the proceeds of the trade should be paid to the king and a minimum of $40,000 \mathrm{lb}$. of Spanish tobacco imported. This scheme was merely one of the many expedients devised by the Lord Treasurer to supplement the king's revenue. The company found themselves forced to accept it. The execution of the contract gave rise, however, to great disputes and dissensions within the companies, and little profit accrued to the royal revenue. The contract was annulled in the following year (1623).

About the same time the Court party within the Virginia company petitioned the king for its dissolution. A commission was appointed by the Privy Council to inquire into the state of the colony. Their report was unfavourable. It was in vain for the company to plead that the colony was still suffering from the massacre of the previous year. It was decided that the government of the colonies should be taken over by the Crown. The charters of both companies were annulled in 1624. The government of the colonies was put into the hands of a commission of twelve appointed by the king, who took into his own hands the monopoly of the tobacco trade. 


\section{VI}

Agri-

A most important feature of the Tudor policy had been the culture. encouragement of tillage. ${ }^{1}$ Herein James followed in his predecessors' footsteps. The Elizabethan statutes were re-enacted, but few or no innovations were introduced.

The enclosing of land for sheep-farming which had taken place during the sixteenth century had not only greatly decreased the area of arable land, but had also considerably impoverished many of the rural districts. The attention of the king and Privy Council were directed to the matter by the outbreak of riots, chiefly in Northamptonshire, in May I607, against enclosures and encroachments on common lands. The riots were soon suppressed; and a commission was appointed to inquire into the extent of enclosures. ${ }^{2}$ The articles of inquiry were drawn up on much the same lines as those of the commission of $1517 .^{3}$ The commissioners were directed to inquire (by the oath of twelve lawful men of the county) to what extent enclosure had taken place since the twentieth year of Elizabeth, and to what extent depopulation had resulted therefrom. They were also to find out 'how many still occupy the land and sett poor men and others in their dwelling houses, or leave them wide.'

The reports of the commissioners ${ }^{4}$ of the five midland counties are preserved, viz. : of Bedford, Warwick, Leicester, Northampton, and Buckinghamshire. These reports show that enclosure of land for sheep farming had practically ceased. Large areas of land, however, lay idle, and many

1 See Bacon, Hist. of Henry VII. p. 93. ' The king (by encouraging tillage) did secretly sow Hydras' teeth, whereupon rise up armed men for the service of the kingdom.'

${ }^{2}$ See Cunningham, Growth of English Industry and Commerce: Mod. Times, pp. 52, 53, footnotes.

3 Leadam, Domesday of Enclosures.

4 See P.R. O. Depopulation Reports, 5 Jac. I. I am indebted to Mr. Hall for having most kindly drawn my attention to the reports of this commission. Cases of enclosure within five or six years of the date of the inquiry are rare; the majority occur before 1595. The reports for the county of Northampton are of much greater length than those of the other counties. 
villages were depopulated as a result of enclosure in the past.

In order to keep up a fair level of prices, and so encourage the farmer, a proclamation was issued in the first year of the reign, permitting the exportation of corn in English ships when the price of wheat did not exceed $26 s .8 d$. per quarter, the price of rye $15 s$, per quarter, and barley $14 s$. per quarter. This proclamation was renewed at the end of the reign, after a general rise in prices had taken place, and the limit was raised for wheat to $32 s$. per quarter, for rye to $20 s$. per quarter, and for barley to $16 s$. per quarter.

The reign was remarkable for the frequency of bad seasons. Dearth prevailed in the country districts, owing to the failure of the crops, in the years $1607-9,1614$, and $1621-2$.

The large quantities of corn imported at these times was regarded as one of the causes of the increasing scarcity of money. As a remedy for this it was advised that the example of the Low Countries and the Empire should be followed, and that national stores of grain should be kept to provide for years of dearth. 'Amsterdam,' it was stated, ' is never without 700,000 quarters of corne, . . . and none of this groweth in their own country. A dearth in England, France, Spain, Italy is truly observed to enrich Holland seven years after. For example, the last dearth, six years past (i.e. that of 1614 ) the Hamburgers, Embdeners, and Hollanders out of their store houses furnished this kingdom; and from Southampton, Exeter, and Bristowe in a year and a half carried away near $200,000 l$. from these three ports only.' ${ }^{2}$ In accordance with this suggestion a proclamation was issued ordering the establishment of public magazines for corn. Commissioners were

1 See Diary of William Yonge (Camden Soc. vol. 1xi.), and Rogers, Hist. of Agriculture and Prices. Great local variations of prices occurred. It is difficult to estimate the dearth of corn by the price, as a general rise in prices took place in the course of the reign; while in time of actual scarcity of money the phenomenon of dearth of corn and low prices was observed. See Sir R. Maddison, 'Note concerning the helpes of trade,' July 2, I623, Add. MSS. 2434.

2 See Keymer, Book of Observations touching Trade and Traffique beyond the Seas, 1620. Lansdowne MSS., 162. 
appointed and empowered to purchase corn and deposit it therein, when the price of wheat fell below 32s. per quarter, of rye below $18 \mathrm{~s}$. per quarter, and of barley below $16 \mathrm{~s}$. per quarter.

An important undertaking begun during the reign, and one in which the crown took an active part, was the reclaiming of waste fen lands. A series of destructive floods in 1607. broke through the embankments protecting the low lands of the eastern counties, and many farms and villages were swamped. A commission appointed to inquire into the extent of waste lands reported that 317,242 acres in the fen district were waste. Various attempts to drain these lands were made. The most notable of these was that made, at the instigation of the king, by Lord Chief Justice Popham. He had adventured considerable sums himself in the undertaking, and organised a company of London merchants and others to share the rest of the burden of expense. The adventurers were to receive as a reward for their work, if successful, two-thirds of the land reclaimed. The attempt, however, failed, and the adventurers lost heavily. In 162 I the king invited Vermuyden, the Dutch engineer, to come over and undertake the draining of Windsor Park. Afterwards the draining of Hatfield Chase was entrusted to him. This work, which was later financed by the Duke of Bedford, was not completed until the following reign.

\section{VII}

Currency. In treating of the economic conditions of the reign of James I. and of the relations of the Crown to trade and the effects of the Crown policy, it is necessary to direct attention to the state of the currency during the period. The first quarter of the seventeenth century was a period of currency difficulty in all countries of Western Europe, and in England it was one of almost chronic scarcity. The scarcity was noticeable from the beginning of the period; it became serious in $16 I I-12$, and the currency crisis reached its 
height in 1622-3. There were special causes which made the period one of currency scarcity in England; chief among these were the decay of export trade of cloth and failure in the harvests. Besides these it is necessary to take into account some of the broad general causes affecting the state of the currency in England and other Western European countries alike. A review of these will show that, though perhaps James may be held responsible in part for the severity of the currency and trade crisis which took place in England, owing to his ill-timed attempt to alter the course of the cloth trade, his tamperings with the currency itself, and his general disregard of national trade interests in his foreign policy, yet there were other causes beyond his control which made currency difficulty inevitable.

These causes were the increase in the supply of the precious metals from America and the unevenness in its distribution. After the discovery and exploitation of the Potosi silver mines, the annual increase in the stock of silver was enormous. But it is estimated by Soetbeer ${ }^{1}$ that the full effect of this increase was not felt until the first quarter of the seventeenth century. It is for this reason that the period is one of universal monetary confusion. The difficulties in the way of even distribution enhanced the confusion, and everywhere violent oscillations occurred in the ratios of value of gold to silver. The average ratios for Western Europe have been calculated as follows by Soetbeer :

$$
\begin{array}{lllll}
1581-1600 & \ldots & \ldots & \ldots & 1: 12 \\
1601-1620 & \ldots & \ldots & \ldots & 1: 12 \cdot 5 \\
1620-1640 & \ldots & \ldots & \ldots & 1: 14
\end{array}
$$

While the average of the middle period ( $1601-1620)$ was not much above that of the preceding period (I $581-1600$ ), the limits of the variations were much wider. After 1625, the ratio rose suddenly and rapidly everywhere; for by this time the increased supply of silver was fairly evenly distributed.

1 See Soetbeer, Edelmetallproduktion in Werthverhältniss zwischen Gold und Silber seit der Entdeckung Amerikas bis der Gegenwart. Gotha, 1874. 
The years 1620-1624 saw grave currency crises both in England and Germany. Many reasons contributed to impede the distribution of the precious metals. Not only were there great difficulties and dangers in the way of its transport, but these were increased, and ordinary trade intercommunication hampered, by the wars of the period. Moreover, the inflow of the precious metals from America caused the rapid decline in the supply from other guarters. This meant that the channels through which gold and silver flowed into Western Europe were changed. All American metal (except that which fell into the hands of English or other privateers) had to pass through Spain. This point is important in its effect on the distribution of the metals. For though there could be no comparison between the outputs of American and European silver mines, the freedom and natural course of its distribution was very much more hampered in the former case. For Spain was not a great commercial nation. Her wealth consisted chiefly in her American gold and silver. This, according to the prevailing idea of the time, she would have kept within the country as far as possible. It was drafted away in payment of the emperor's debts \&c., and used in the service of his wars rather than distributed in the ordinary course of trade.

The complaint that was frequently made, and to which, by some, the scarcity prevalent in England and elsewhere in the early seventeenth century is partly attributed, viz. 'we no longer have silver from High Germany as we used,' has thus some basis. The silver, instead of passing almost immediately into circulation as formerly, when the chief silver mines were in the hands of the Augsburg merchants, was restricted in its outflow, and its distribution was unequal. This inequality was increased also by conscious interference with the exchanges, though the extent to which this was attempted was much exaggerated in contemporary writings. The interference was of two kinds: ( $a$ ) deliberate attempts on the part of governments or trading communities to keep the exchanges at a certain level; $(b)$ the handling of the exchanges for 
private gain. To what extent the latter actually existed it is difficult to determine, but it is easy to see that the monetary confusion prevailing everywhere gave the opportunity for handling the exchanges to any one astute enough to do so.

The failure of the great Antwerp and Augsburg financial houses, the Fuggers \&c., at the close of the sixteenth century, following on the repeated bankruptcies of the Spanish and French Crowns, threw the monetary world into confusion, and considerably enhanced the difficulties in the way of even distribution.

In spite of the fact that Europe was neither adequately nor evenly supplied with the precious metals, the outflow of silver to the East had already begun. This is a fertile source of complaint among the English tract writers, and though their attacks on the East India Company in this connection are not untinged with jealousy, the grievance, at a time when an actual insufficiency of currency existed at home, was perhaps a real one.

There were also many practical difficulties in the way of even distribution. No country could boast of a satisfactory currency.

The process of minting was slow ${ }^{1}$ and uncertain in its results. The coins issued were frequently inaccurate and light-weight. The currency was open in all countries to the dangers of debasement. It was a period of needy princes, and there were few, if any, who could withstand the temptation of tampering with currency.

In England throughout the reign of James I. the state of the currency was a cause of grave anxiety both to merchants and statesmen. Not only was the currency itself in an unsatisfactory condition, but there was a continual drain of bullion to the Continent. Contemporary opinion was divided as to the cause of this. By some the drain of specie was attributed to the over-valuation of silver in terms of gold, by

1 Ruding, vol. i. p. 372, 1617. 'By the death of Sir R. Martin, Master of the Mint, a stop was put on the working of the Mint, and those who brought bullion could not have it made into money.' 
others to the 'unfavourable balance of trade.' It is probable that there was some truth in both opinions.

Elizabeth at the close of her reign had made an attempt to restore the currency, and a new coinage was issued in 1601 . The benefit of this measure, sound in itself, was marred by the fact that the ratio of gold to silver, at which the coins were issued, was lowered instead of raised. ${ }^{1}$ This error James attempted to remedy in his re-issues of 1604 and 1605 . The difficulty of adjusting the ratio in accordance with the everchanging variations on the Continent was very great. In spite of the great oscillations of ratio which took place, there was a general tendency to rise, as the distribution of the precious metals gradually took place. The relief effected by the measures of 1604 and 1605 was only temporary. The drain continued, and became more rapid as the confusion in the cloth trade increased. The falling-off in the export trade of cloth, \&c., was undoubtedly one of the causes of the drain of bullion, while the monetary scarcity which resulted served to enhance the severity of the industrial crisis.

Attempts were made to check the drain by means of proclamations forbidding the export of bullion under penalty. These proved futile. In 1609 the drain was already so serious as to lead to the appointment of a commission of inquiry. The report of the commissioners declared the causes of the drain of bullion and the consequent scarcity to be : (a) that the ratio between gold and silver was not the same as in other countries; (b) the abuse of the exchange. The former would not be sufficient in itself to produce the evil ' if there were betwixt the countries due course holden in exchange of money ; but that is not so.' The remedy proposed was therefore the reform of the abuse of exchange. The business of banking and exchange was in the hands of the Goldsmiths' Company, who were charged with working the exchanges to their own profit, and it was proposed to revive the office of Royal Exchanger. The goldsmiths

' See Shaw, Hist. of Currency, p. 152. 
petitioned against this, and the proposal was abandoned for the time being. That great want of uniformity in the rates of exchange existed is evident from the contemporary complaints made. It was alleged that the goldsmiths and other merchants gave a higher rate for silver than the Mint price. The East India Company proposed in their own interest that ' all merchants and goldsmiths be prohibited from giving a higher price than the king for silver, except the East India Company.' 1

In I6I I the Crown was led to tamper with the currency under pressure of revenue difficulties, though the alleged reason was to remedy the monetary scarcity. The nominal values of the coins, gold and silver, were raised ro per cent. This was followed in 1612 by a debasement of the standard of the coinage. This measure was opposed by Sir Robert Cotton, who advised an attempt to diminish the imports and increase the exports.

Sir Richard Martin, Master of the Mint, gave his opinion in favour of debasement. 'There are,' he wrote, 'only three meanes of setting his majestie's mint at work :

'(I) The limitation of merchants in bringing over foreign commodities.

'(2) By crying up the moneys to a higher value.

'(3) By imbasing the moneys.' ${ }^{2}$

The first he declared to be the only true means, but ' inasmuch as it will aske longer time for the settling thereof, which the present necessitie will not afford,' another means must be sought. The crying up of moneys to a higher value

${ }^{1}$ See $D . S$. P., Jac. I, vol. lxix. 8.

2 He goes on: 'For yf the shillinge should be raysed to thirteene or fourteene pence, the merchant and vittler would presently rayse their commodities accordinglie, and soe landlords, officers and labourers lyving upon their former rents, fees and labours, receaving noe more than they were wont, shall pay more for their maintenance than heretofore, by one sixth the part, soe that in tyme it would come to passe that landlords in whom onlie there may be a power to relieve themselves, their leases being expired, would raise their rents accordinglie, only those that have great store of money should be gayners by this course.' The tract is signed 'Sir Ric. Martin, Kt. master of the Mint, excellently experienced in money business.' See Add. MSS. 34324, fol. 64 .

N.S.-VOL. XIII. 
he proved to be useless. It might stop exportation, but would not conduce to importation of bullion. 'Soe that the first course beinge not presently to be put into execution, and the second not convenient, yt remayneth that if any alteration be made yt must be by meanes of the last, namelye, by imbasing the moneys, with such moderation as may save the present necessitie and yett bringe noe discreditt on the moneys.'

Debasement of the coinage was decided upon, and the pound troy of gold (22 carat) was coined into $40 l$. 18s. $4 d{ }^{1}$ Meanwhile, however, the actual scarcity of money was so great that there was insufficient to carry on ordinary business; leaden tokens, issued by private merchants, were in circulation. The use of these was prohibited in I6 3 , and a patent granted to Lord Harrington for the issue of copper farthings to take their place.

The needs of the king's purse became more pressing as the scarcity increased, and the proclamations against the excessive use of the precious metals for plate, and gold and silver thread, as well as those against the exportation of bullion, were more stringently enforced in the king's interest. In I6I7 James took into his own hands the monopoly of making gold and silver thread. In 1618 offenders against the proclamation forbidding exportation of bullion were tried before the Star Chamber. In that year James took advantage of the unpopularity of the Dutch merchants, and eighteen of the wealthiest were accused before the Court of Star Chamber of exporting bullion, and fined large sums. The fines were so large (ranging from 2,000l. to 20,000l.) that the States interceded on behalf of the merchants. The Solicitor-General alleged that 7,000,000l. had been exported, and though this was shown to be impossible by Sir Noel de Caron, the fines, amounting to $132,000 l$. were imposed. These were reduced, owing to the inability of many of the offenders to pay the required sums. Eventually 34,cool. worth of

' See Ruding, vol. i. p. 367 . 
silver was paid into the Mint to be recoined, ${ }^{1}$ and the king cancelled a loan of $20,000 l$. borrowed previously from the Dutch merchants.

In I6I9 a meeting of the Privy Council was held to discover some remedy for the scarcity, and merchants of the East India, Turkey, French, Spanish, and East land and other companies were invited to give their opinions. The suggestion of appointing a Royal Exchanger was again brought forward, and again petitioned against by the Goldsmiths' Company, who suggested as the best remedial measure to be to increase the denominational value of the coins. This advice was followed, and the coinage of 1619 issued, and the standard of the coins was again lowered. ${ }^{2}$ This was the last change in the coinage made during the reign. In 1620 the condition of the cloth trade and the scarcity of money attracted the notice of Parliament, and a debate on the subject took place. Dissolution, however, took place before any active measures of remedy could be initiated.

The most important step taken was the appointment of the commission of the Privy Council, for inquiry into the decay of trade and scarcity of money already mentioned in Section III. The king also attempted to find a solution of the currency difficulty and directed various persons, merchants and others, to submit to him in writing their opinions on the subject ; among these were Mandeville, then President of the Council, Mun, Maddison and others. Sir Hen. Mandeville was first appealed to. His views flavoured strongly of Malynes'. He attributed the evil to the abuse of the exchanges, and advised 'a restraint on the price of foreign wares, which have risen in price two thirds, liberty of free trade, the execution of the Statute of Strangers'

1 See Introd. to Huguenot Soc. Proceedings, vol. i. Moens, and $A d d$, MSS. 34324, fol. Io9.

2 1619. 'The gold angel was reduced in weight from $71 \frac{1}{9}$ grains to $64 \frac{11}{15}$, a reduction equivalent to an increase of $\frac{1}{11}$ in denominational value (Shaw, p. 139). The lb. troy was cut into 66 shillings. 
Employments, and there will be noe doubt but that the native commodities of your kingdom and the industry of your people will dayly be improved, and the outward trade of your merchants be restored again to the former riche and flourishing estate and so on. ${ }^{1}$ The king was not satisfied with this report and directed that it should be laid before certain notable merchants. The 'Humble Report' 2 drawn up by them ten days later was a refutation of Mandeville's pamphlet, and embodied sounder views on the theory of the exchanges and the balance of trade. Mun's hand is traceable in its composition; and it contains views expounded later both by him and Misselden. ${ }^{3}$

It was demonstrated that the loss on the exchange was not so great as had been declared $;^{4}$ and while conceding that some relief might be found in arranging a treaty with other countries 'for a just correspondence to be houlden between this Realm and those parts in the valewe of Coynes' it was argued, that as long as 'we spend in this kingdom a greater value of forrain commodities than forrain parts doe of ours, so long must there of necessity be exported

1 See Add. MSS. 32434, Casar Papers, fol. I 52, dated May I, 1622.

2 Mr. Bell (of the East India Company), Thos. Mons (i.e. Mun), Mr. Thos. Jennings (an adventurer in East India Company), Mr. Wood ye Goldsmith, Mr. Skinner (of the East India Company), Mr. Keneidee (he signs himself Kendrick in the Humble Report). See Add. MSS. 32434, fol. 155.

3 The Preface of Misselden's Free Trade is dated June 8, I622; the Circle of Commerce was not written till after the appointment of the Commission. Mun's Tract in defence of the East India trade had appeared 1621.

${ }^{4}$ See Add. MSS. 34324, fol. I55. Mandeville calculated the loss in the exchange with the Low Countries to amount to $3 s$. $2 d$. on the $1 l$. sterling. Mun and the rest prove it to be only $2 \frac{1}{2} d$. on the $I l$.

The Report goes on: 'This is so necessarilie true as that noe lawe, no treaty, no losse to the merchant, nor par upon the exchange, nor danger to the exporter can prevent it, but if it be mett with all in one part yett it must out in another ... But if this wast of forraine wares be kept within compasse of our commodities vented in forraine parts, then though the neighbouring states enhance the Coyne, though the exchange goe free at the pleasure of the merchants contracting it, though the lawes against exportation and Strangers ymployment slepe, and all men be suffered to carry moneye wherever he will, yet this over. ballance of our commodities will force it again with an increase by a necessitie of nature beyond all resistance; other remedye than this we conceive none to be effectual.' (Add. MSS. 34324, fol. I67.) 
as much of our moneys as will ballance and level that difference.' This tract was answered by another, ${ }^{1}$ and a small pamphlet war followed ; the controversy was carried on afterwards at the table of the Commission of Trade. ${ }^{2}$

No attempt was made to remedy the scarcity of money by introducing any currency reform.

The crisis in trade and currency was gradually abating when the reign closed.

\section{VIII}

As we have seen, the years $1622-23$ were marked by failure and mishap for England on many sides. The actual scarcity of currency was so great as to hinder the conduct of ordinary every-day business. The distress in the clothing districts led to risings and outbreaks. ${ }^{3}$ Failure of the harvest in these years in many parts of England made matters worse, and relief more difficult. The cloth trade received another serious rebuff in the Pragmatic Sanction issued against English cloths towards the close of 1622 , and again, with more strict orders for enforcement, in February 1623 . In the East Indies the heat of the struggle between the English and the Dutch, in defiance of home governments, was daily becoming more intense, reaching a climax in the massacre at Amboyna. in 1623. James's foreign policy was complicating matters, his friendly negotiations with Spain were not only increasing the discontent at home, but lowering the prestige of England abroad, and especially in the eyes of the Dutch. The

\footnotetext{
1 Unsigned, but probably written with the help of Malynes, whose writings it resembles closely both in language and matter.

2 The writers, besides Mandeville and Mun, were Malynes, Sir Ralph and Sir Ric. Maddison. Nine of these tracts are preserved, together with notes in Cæsar's hands of the debates on the scarcity at a few of the meetings of the Council (or Commission?) in the Casar Papers, Add. $M$ sS. 34324. Mun and Sir Ralph Maddison were among the original members of the Commission. Misselden was not of the number, he was carrying on the controversy with Malynes in the outside world. His Circle of Commerce was published shortly after the appointment of the Commission.
}

${ }^{3}$ See Diary of William Yonge, Camden Soc. Pub. vol. xli. 
intensity of the distress made action on the part of the Government necessary.

When Parliament met, in 1623 , its attention was directed to the condition of trade, and a committee was appointed to inquire into and report on the subject. The chief causes of decay of trade were reported to be monopolies and impositions. 'If these burdens continue,' it was alleged, 'they will tend to the utter destruction of the Kingdom.' 1

In dealing with them, the committee urged that care should be taken not to grieve the king with questions of right or diminution of revenue. As a result of this the Statute against Monopolies was drafted and passed in May 1624. It was no doubt the critical condition of trade and industry that induced the king to give his consent to this Act. By it the determination of the validity of all patents of monopolies was put into the hands of the common law judges. Certain of the principal monopolists, viz. the great companies, were exempted from the Act. For political reasons the removal of impositions was not brought forward by Parliament.

The committee of the Privy Council,' which continued to sit until the end of the reign, achieved little beyond a more active administration of the poor law, to alleviate the distress in the country districts, and suppress the riots \&c. to which the distress and decay of trade had given rise in the clothing districts.

Side by side with the industrial distress and decay of trade and monetary scarcity which has been dwelt upon at such length here, it must be admitted that considerable prosperity existed also.

Large fortunes were amassed by many of the London merchants, especially by those engaged in the East India trade. Such undertakings, by private enterprise, as the construction of the New River by Hugh Myddelton, to supply London with water; the foundation of the Charter House School by Sutton, \&c., give evidence of wealth and prosperity. Moreover the same is witnessed in the rapid growth of

\footnotetext{
' See C. J., vol. i. April 1624 .
} 
London, which took place at this time, and the restraint of which is the subject of repeated proclamations of the king.

At the end of the reign it was clear that, in spite of all the distress and the difficulties in the way of trade, great advance had been made in many directions. The East India Company, in spite of the rebuffs from the Dutch in the Moluccas, had obtained a firm foothold in the trade with the mainland of India and with Persia. The foundation of a new England in America, begun in 1607 , reinforced by subsequent bands of emigrants, had been achieved in the face of many difficulties. In Ireland some kind of settlement had been attained, and the plantation of the province of Ulster by English and Scotch colonists begun.

The aspect of home trade and industry at the close of the reign was not very bright, and difficulties in the cloth trade and in the maintenanse of the poor inevitably followed. No crisis equal in severity to that of $1622-3$ occurred. This may be attributed in part at least to the fact that Charles I. was fortunate in this, that the forces contributing to monetary and trade difficulties under James had in great measure ceased to exist and that Western Europe was fairly adequately and evenly supplied with the precious metals. 